University of Nebraska - Lincoln

DigitalCommons@University of Nebraska - Lincoln

Publications from USDA-ARS / UNL Faculty

U.S. Department of Agriculture: Agricultural

Research Service, Lincoln, Nebraska

2009

\title{
Leaf isoprene emission rate as a function of atmospheric $\mathrm{CO} 2$ concentration
}

\author{
Michael J. Wilkinson \\ University of Colorado \\ Russell K. Monson \\ University of Colorado \\ Nicole Trahan \\ University of Colorado \\ Stanfield Lee \\ University of Colorado \\ Erin Brown \\ University of Colorado \\ See next page for additional authors
}

Follow this and additional works at: https://digitalcommons.unl.edu/usdaarsfacpub

Part of the Agricultural Science Commons

Wilkinson, Michael J.; Monson, Russell K.; Trahan, Nicole; Lee, Stanfield; Brown, Erin; Jackson, Robert B.; Polley, H. Wayne; Fay, Philip A.; and Fall, Ray, "Leaf isoprene emission rate as a function of atmospheric CO2 concentration" (2009). Publications from USDA-ARS / UNL Faculty. 440.

https://digitalcommons.unl.edu/usdaarsfacpub/440

This Article is brought to you for free and open access by the U.S. Department of Agriculture: Agricultural Research Service, Lincoln, Nebraska at DigitalCommons@University of Nebraska - Lincoln. It has been accepted for inclusion in Publications from USDA-ARS / UNL Faculty by an authorized administrator of DigitalCommons@University of Nebraska - Lincoln. 


\section{Authors}

Michael J. Wilkinson, Russell K. Monson, Nicole Trahan, Stanfield Lee, Erin Brown, Robert B. Jackson, H. Wayne Polley, Philip A. Fay, and Ray Fall 


\title{
Leaf isoprene emission rate as a function of atmospheric $\mathrm{CO}_{2}$ concentration
}

\author{
MICHAEL J. WILKINSON*, RUSSELLK. MONSON*†, NICOLE TRAHAN*, STANFIELD \\ LEE*, ERIN BROWN*, ROBERT B. JACKSON \\ RAY FALL十 \\ ${ }^{*}$ Department of Ecology and Evolutionary Biology, University of Colorado, Boulder, CO 80309-0334, USA, †Cooperative Institute \\ for Research in Environmental Sciences, University of Colorado, Boulder, CO 80309, USA, †Department of Biology, Nicholas School \\ of the Environment, Duke University, Durham, NC 27708, USA, §Grassland Soil and Water Research Laboratory, U.S. Department \\ of Agriculture, Temple, TX 76502, USA, -Department of Chemistry and Biochemistry, University of Colorado, Boulder, CO 80309, \\ USA
}

\begin{abstract}
There is considerable interest in modeling isoprene emissions from terrestrial vegetation, because these emissions exert a principal control over the oxidative capacity of the troposphere. We used a unique field experiment that employs a continuous gradient in $\mathrm{CO}_{2}$ concentration from 240 to 520 ppmv to demonstrate that isoprene emissions in Eucalyptus globulus were enhanced at the lowest $\mathrm{CO}_{2}$ concentration, which was similar to the estimated $\mathrm{CO}_{2}$ concentrations during the last Glacial Maximum, compared with 380 ppmv, the current $\mathrm{CO}_{2}$ concentration. Leaves of Liquidambar styraciflua did not show an increase in isoprene emission at the lowest $\mathrm{CO}_{2}$ concentration. However, isoprene emission rates from both species were lower for trees grown at 520 ppmv $\mathrm{CO}_{2} \mathrm{compared}$ with trees grown at $380 \mathrm{ppmv} \mathrm{CO}_{2}$. When grown in environmentally controlled chambers, trees of Populus deltoides and Populus tremuloides exhibited a $30-40 \%$ reduction in

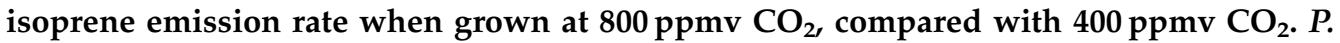
tremuloides exhibited a $33 \%$ reduction when grown at $1200 \mathrm{ppmv} \mathrm{CO}_{2}$, compared with 600 ppmv $\mathrm{CO}_{2}$. We used current models of leaf isoprene emission to demonstrate that significant errors occur if the $\mathrm{CO}_{2}$ inhibition of isoprene is not taken into account. In order to alleviate these errors, we present a new model of isoprene emission that describes its response to changes in atmospheric $\mathrm{CO}_{2}$ concentration. The model logic is based on assumed competition between cytosolic and chloroplastic processes for pyruvate, one of the principal substrates of isoprene biosynthesis.
\end{abstract}

Keywords: atmospheric chemistry, $\mathrm{CH}_{4}$, climate change, forests, global change, $\mathrm{O}_{3}$

Received 9 May 2008 and accepted 26 July 2008

\section{Introduction}

Isoprene $\left(\mathrm{C}_{5} \mathrm{H}_{8}, 2\right.$-methyl-1,3-butadiene $)$ is the base unit of the isoprenoid family of organic chemical compounds (e.g., monoterpenes and carotenoids) and is emitted to the atmosphere from a variety of both natural and anthropogenic sources (Harley et al., 1999; Monson \& Holland, 2001; Lerdau \& Gray, 2003). At the global scale, biogenic emissions of isoprene dominate

Correspondence: Russell Monson, Department of Ecology and Evolutionary, Biology, University of Colorado, Boulder, CO 803090334, USA, fax: + 1303492 8699, e-mail:

Russell.Monson@colorado.edu the flux of biogenic volatile organic compounds (BVOCs) from vegetation to the atmosphere, and are arguably the dominant control over tropospheric photochemistry above continental regions (Fehsenfeld et al., 1992; Monson, 2002). Global isoprene emissions account

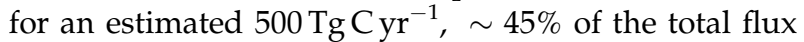
of BVOC (Guenther et al., 1995; Potter et al., 2001; Shim et al., 2005). The emission of isoprene affects the regional and global tropospheric hydroxyl radical $(\mathrm{OH})$ concentration (Fehsenfeld et al., 1992), has the potential to modify regional ozone pollution (Pierce et al., 1998), and can lead to secondary aerosol formation (Claeys et al., 2004). Hence, accurate estimates for the regional and global flux of isoprene from forest ecosystems are 
required to understand controls over the earth's albedo, and because of its interactions with $\mathrm{OH}$, controls over the lifetime of the important climate greenhouse gas $\mathrm{CH}_{4}$ (Houweling et al., 1998; Poisson et al., 2000; Valdes et al., 2005).

Biogenic emissions of isoprene were first reported by Sanadze (1957), who later showed that isoprene emissions are sensitive to changes in photosynthetic photon flux density (PPFD) and atmospheric $\mathrm{CO}_{2}$ concentration $\left(\left[\mathrm{CO}_{2}\right]\right)$ (Sanadze, 1964). Subsequent studies revealed that a tight connection exists between isoprene emissions and photosynthetic $\mathrm{CO}_{2}$ assimilation (Tingey et al., 1981; Monson \& Fall, 1989; Loreto \& Sharkey, 1990, 1993; Delwiche \& Sharkey, 1993). This metabolic connection was clarified following the discovery that photosynthetically produced glyceraldehyde 3-phosphate (G3P) is required in the chloroplastic methyl erythritol 4-phosphate (MEP) pathway, which is responsible for biogenic isoprene production (Lichtenthaler et al., 1997). The dependence of isoprene biosynthesis on photosynthetic G3P, however, cannot explain the response of isoprene emission rate $\left(\mathrm{I}_{\mathrm{s}}\right)$ to changes in atmospheric $\left[\mathrm{CO}_{2}\right]$, which tends to vary inversely with $\left[\mathrm{CO}_{2}\right]$; opposite to that observed for photosynthetic $\mathrm{CO}_{2}$ assimilation rate (Sanadze, 1964; Monson \& Fall, 1989; Loreto \& Sharkey, 1990). Evidence has accumulated recently that the $\mathrm{CO}_{2}$ response of $\mathrm{I}_{\mathrm{s}}$ is due to changes in the partitioning of phosphoenol pyruvate (PEP) between the cytosol and chloroplast, which in turn influences the availability of the second initial substrate in the MEP pathway, pyruvate (Rosenstiel et al., 2003). The $\mathrm{CO}_{2}$-dependence of $\mathrm{I}_{\mathrm{s}}$ has implications for both the response of emissions to future changes in the atmospheric $\left[\mathrm{CO}_{2}\right]$, and the response of leaf-level emissions to changes in the intercellular $\left[\mathrm{CO}_{2}\right]$ $\left(\mathrm{C}_{\mathrm{i}}\right)$ that might occur during drought, changes in incident PPFD, the leaf-to-air water vapor pressure deficit, and temperature.

Recently, the results of several modeling studies suggest that an increase in the flux of isoprene from the biosphere can be expected due to increases in net primary productivity (NPP) and global temperatures (Brasseur et al., 1998; Johnson et al., 1999, 2001; Zeng \& Pyle, 2003; Lathiere et al., 2005; Tao \& Jain, 2005; Liao et al., 2006). However, these models do not account for the decrease in $\mathrm{I}_{\mathrm{S}}$ with increasing atmospheric $\left[\mathrm{CO}_{2}\right]$ (Sanadze, 1964; Monson \& Fall, 1989; Rosenstiel et al., 2003; Centritto et al., 2004; Scholefield et al., 2004; Possell et al., 2005), a feedback that works in the opposite direction to the positive effects of temperature and NPP under future global change scenarios (Monson et al., 2007). To our knowledge, there has only been one study that attempts to quantify the effects of $\left[\mathrm{CO}_{2}\right]$ on $\mathrm{I}_{\mathrm{s}}$ with a view to improving predictive models
(Possell et al., 2005), and only two that have tried to introduce the $\mathrm{CO}_{2}$-effect into global scale models of $\mathrm{I}_{\mathrm{s}}$ in a projected future atmosphere (Arneth et al., 2007, 2008). The inclusion of the $\mathrm{CO}_{2}$ response of $\mathrm{I}_{\mathrm{s}}$ in the current generation of atmospheric chemistry models has been hampered by two important factors: (1) lack of knowledge about the influences of changes in atmospheric $\left[\mathrm{CO}_{2}\right]\left(\mathrm{C}_{\mathrm{a}}\right)$ over longer time scales vs. changes in $\mathrm{C}_{\mathrm{i}}$ over shorter time scales, and (2) lack of a quantitative framework to describe leaf-level responses of $\mathrm{I}_{\mathrm{S}}$ to long-term and short-term $\mathrm{CO}_{2}$ influences. Therefore, to improve our understanding in these areas, we investigated both long-term and short-term effects of different $\mathrm{CO}_{2}$ concentrations on $\mathrm{I}_{\mathrm{s}}$ using leaves from aspen (Populus tremuloides), cottonwood (Populus deltoides), sweetgum (Liquidambar styraciflua), and eucalyptus (Eucalyptus globulus) trees. We used these results to develop a quantitative algorithm that can be used to scale $I_{s}$ at the leaf level to changes in atmospheric and intercellular $\left[\mathrm{CO}_{2}\right]$, and can be incorporated into larger-scale models that aim to predict regional or global patterns in $\mathrm{I}_{\mathrm{s}}$.

\section{Materials and methods}

\section{Growth of trees in controlled-environment chambers}

Twenty-four 3-year-old cottonwood trees were grown in controlled-environment (light, temperature and $\left[\mathrm{CO}_{2}\right]$ ) growth chambers (Conviron, model PGR 15, Winnipeg, Canada) at the University of Colorado. Twelve trees were placed in an 'ambient' $\mathrm{CO}_{2}$ chamber $(400 \pm 10 \mathrm{ppmv})$ and 12 trees were placed in an 'elevated' $\mathrm{CO}_{2}$ chamber $(800 \pm 15$ ppmv) for 8 weeks. All trees were defoliated before being placed in the chambers so that new leaves developed in the treatment $\left[\mathrm{CO}_{2}\right]$. The trees were moved within the chambers weekly to minimize the effects of within chamber heterogeneity. The trees were grown in $10 \mathrm{~L}$ pots containing commercial potting soil, and fertilized regularly with half-strength Scotts' solution (21:18:18; ScottsSierra Horticultural Products Company, Maryville, $\mathrm{OH}, \mathrm{USA})$. The photoperiod was $14 \mathrm{~h}$ with PPFD of $700 \mu \mathrm{mol} \mathrm{m}^{-2} \mathrm{~s}^{-1}$ measured approximately $30 \mathrm{~cm}$ from the lamps, which represents a distance approximately $25 \%$ through the vertical length of average tree crown. Leaf gas exchange measurements were made on leaves that were growing within this region of the crown. Day/night air temperatures were kept at $25 / 15^{\circ} \mathrm{C}$.

In a second experiment, 24 2-year-old aspen trees were grown in the chambers at different atmospheric $\left[\mathrm{CO}_{2}\right]$ using the same PPFD and temperature regimes described above. We conducted the studies with aspen over two growth cycles, one in which we grew the trees at 400 or $800 \mathrm{ppmv} \mathrm{CO}_{2}$, and one in which we grew 
them at 600 or $1200 \mathrm{ppmv} \mathrm{CO}_{2}$. The same trees were used in the two cycles, with the $400 / 800$ ppmv experiment being conducted first. Between cycles, the trees were defoliated, and the trees from the $400 \mathrm{ppmv}$ treatment were allowed to regrow at $600 \mathrm{ppmv} \mathrm{CO}_{2}$; those from the $800 \mathrm{ppmv}$ experiment were allowed to regrow at $1200 \mathrm{ppmv} \mathrm{CO}_{2}$. The trees were allowed to grow for 8 weeks in each treatment before new measurements were made. At the end of the second experiment, we defoliated all trees once again, and returned five of the trees from each treatment to $400 \mathrm{ppmv}$ for 8 weeks of regrowth. In this third experiment, we noted no significant difference in $\mathrm{I}_{\mathrm{S}}$ between those trees that had been previously grown at the high $\mathrm{CO}_{2}$ treatments (800 and 1200 ppmv) and those that had been grown at the low $\mathrm{CO}_{2}$ treatments (400 and $600 \mathrm{ppmv}$ ), indicating a lack of significant treatment carry-over effects from one experiment to the next $(n=5 ; P=0.4)$. However, there was a significant difference between $\mathrm{I}_{\mathrm{s}}$ at $400 \mathrm{ppmv} \mathrm{CO}_{2}$ in the first experiment and $\mathrm{I}_{\mathrm{s}}$ at $400 \mathrm{ppmv} \mathrm{CO}_{2}$ in the third experiment $(P<0.05)$, indicating that the results were affected by time during the experiment. The exact cause of this time-dependent effect was not analyzed further. However, because of its existence, we analyzed results between the two $\mathrm{CO}_{2}$ treatments within each experiment separately, but did not compare the results of the first experiment ( 400 and 800 ppmv $\mathrm{CO}_{2}$ ) directly with those of the second experiment (600 and 1200 ppmv $\mathrm{CO}_{2}$ ).

\section{Lysimeter $\mathrm{CO}_{2}$ Gradient}

The Lysimeter $\mathrm{CO}_{2}$ Gradient (LYCOG; Temple, TX, USA) is a unique controlled-environment facility for exposing plants to a continuous gradient in atmospheric $\left[\mathrm{CO}_{2}\right]$. The facility consists of two tunnelshaped chambers aligned parallel to each other. Each chamber consists of 10 compartments aligned in series. Pure $\mathrm{CO}_{2}$ is added to air entering the superambient chamber to elevate the initial $\left[\mathrm{CO}_{2}\right]$ to $\sim 520 \mathrm{ppmv}$. Ambient air ( $380 \mathrm{ppmv})$ is introduced to the entrance of the subambient chamber. Photosynthesis by the enclosed vegetation depletes $\mathrm{CO}_{2}$ in the air supply such that by the end of the tunnels, the $\left[\mathrm{CO}_{2}\right]$ is approximately ambient at the end of the superambient chamber and approximately $240 \mathrm{ppmv}$ at the end of the subambient chamber. The $\mathrm{CO}_{2}$ gradient within the chambers is maintained by automatic adjustment of the rate of air flow through each chamber compartment. The chambers transmitted approximately $90 \%$ of the incident PPFD. For a more complete description of the LYCOG site and apparatus, see Polley et al. (2008).

Nine 2-year-old sweetgum trees and nine 2-year-old eucalyptus trees were defoliated and placed in the
LYCOG chambers in early June 2007. Three trees of each species were placed in high $\left[\mathrm{CO}_{2}\right]$ in the superambient chamber. Six trees of each species were also placed in the subambient chamber, three trees in the $\sim 380$ ppmv $\left[\mathrm{CO}_{2}\right]$ compartment and three trees in the $\sim 240$ ppmv $\left[\mathrm{CO}_{2}\right]$ compartment. The trees were watered regularly and new leaves were allowed to develop for 8 weeks in their respective $\left[\mathrm{CO}_{2}\right]$ before leaf gas exchange measurements were carried out. During the 8 -week growth period, better than $80 \%$ of the daytime 20-min readings of $\left[\mathrm{CO}_{2}\right]$ in air exiting the chambers fell within $\pm 25 \mathrm{ppmv}$ of the desired $\mathrm{CO}_{2}$ set points.

\section{Gas exchange measurements}

Measurements of leaf-level gas exchange (including $I_{s}$ ) to changes in $C_{i}$ were made during August 2007 after trees had been individually removed from each chamber and measured over the subsequent $4 \mathrm{~h}$. All measurements were conducted according to the protocols described below during the period of the day between 09:00 and 160:0 hours to avoid the dynamic influences of early morning and late day environments on $\mathrm{I}_{\mathrm{s}}$. Additional measurements were conducted between dawn and dusk to determine the effect of different $\left[\mathrm{CO}_{2}\right]$ on model estimates of the diurnal flux of isoprene from sweetgum trees.

To investigate both the long-term (weeks to months) and short-term (seconds to minutes) effects of changing $\left[\mathrm{CO}_{2}\right]$ on $\mathrm{I}_{\mathrm{s}}, \mathrm{CO}_{2}$ assimilation rate and leaf conductance, gas exchange measurements were made at $25^{\circ} \mathrm{C}$ leaf temperature and $1500 \mu \mathrm{mol} \mathrm{m}^{-2} \mathrm{~s}^{-1}$ PPFD for trees from the growth-chamber experiments and $30^{\circ} \mathrm{C}$ and $1000 \mu \mathrm{mol} \mathrm{m}{ }^{-2} \mathrm{~s}^{-1} \mathrm{PPFD}$, for trees from the $\mathrm{CO}_{2}$ gradient. Gas exchange measurements conducted on trees from the growth chamber experiments were carried out by removing the trees from the chambers and subjecting a portion of an intact leaf to a range of $\left[\mathrm{CO}_{2}\right]$ in the leaf cuvette. Similarly, gas exchange measurements in the LYCOG experiments were conducted after trees were removed from their respective chamber compartments. Here, measurements were carried out only at $\left[\mathrm{CO}_{2}\right]$ corresponding to the $\left[\mathrm{CO}_{2}\right]$ at which the leaves developed.

Leaf gas exchange measurements were conducted using a portable photosynthesis system and 'broadleaf' cuvette (model 6400, LiCor Inc., Lincoln, NE, USA). The cuvette was coupled to either a chemiluminescence fast isoprene sensor (model FIS; Hills Scientific, Boulder, CO, USA) or to a proton transfer reaction-mass spectrometer (PTR-MS; Ionicon GmbH, Innsbruck, Austria) to measure isoprene concentration in the cuvette air. Air delivered to the portable photosynthesis system was scrubbed of ambient VOCs and ozone using a clean air generator (model 737, Aadco Inc., Cleves, OH, USA). The FIS was 
calibrated each day by serial dilution of a 6 ppmv isoprene gas standard. Calibration curves were conducted at five isoprene concentrations from 0 to $400 \mathrm{ppbv}$. The PTRMS was operated at 125 Townsend $\left(1.25 \times 10-17 \mathrm{~V} \mathrm{~cm}^{-1}\right)$ to reduce compound fragmentation.

\section{Statistical analysis}

To evaluate the effects of different $\left[\mathrm{CO}_{2}\right]$ on $\mathrm{I}_{\mathrm{s}}$, one-way analysis of variance (ANOVA) was conducted on data collected from sweetgum and eucalyptus trees. A oneway ANOVA was also conducted on $\mathrm{I}_{\mathrm{s}}$ collected from all aspen trees grown at $400 \mathrm{ppmv} \mathrm{CO}_{2}$ to determine if there were significant treatment carry-over effects between experiments. Student's $t$-tests were carried out on data collected from the controlled environment chambers (aspen and cottonwood) to determine if differences in $\mathrm{I}_{\mathrm{s}}$ between $\mathrm{CO}_{2}$ treatments were significant. Statistical analysis was carried out using SAS statistical software (Version 9.1).

\section{Results}

Response of $\mathrm{I}_{S}$ to changes in $\mathrm{CO}_{2}$ concentration during leaf growth (long-term response)

Differences in the atmospheric $\left[\mathrm{CO}_{2}\right]$ that persist across time scales of weeks to months, the same time scale across which leaves develop and grow, are likely to exert a control over $I_{s}$ through adjustments in gene expression, and the production of a metabolic system uniquely 'tuned' to the atmospheric $\mathrm{CO}_{2}$ regime. We refer to this type of adjustment as the 'long-term response'. For trees grown at the LYCOG project, $\mathrm{I}_{\mathrm{s}}$ was approximately $30 \%$ and $18 \%$ lower, respectively, for eucalyptus and sweetgum trees grown at $520 \mathrm{ppmv}$ $\mathrm{CO}_{2}$, compared with trees grown at $240 \mathrm{ppmv} \mathrm{CO}_{2}$ (Fig. 1). Eucalyptus leaves also exhibited significantly lower $\mathrm{I}_{\mathrm{s}}$ when grown at ambient $\mathrm{CO}_{2}$ compared with 240 ppmv $\mathrm{CO}_{2}(n=3 ; P<0.05)$, an effect that was not observed for sweetgum leaves.

When aspen trees were grown in controlled-environment growth chambers at 400 and 800 ppmv $\mathrm{CO}_{2}, \mathrm{I}_{\mathrm{s}}$ was lower for trees grown at the highest $\left[\mathrm{CO}_{2}\right](n=11$; $P<0.05$; Fig. 2a). Aspen trees grown at $600 \mathrm{ppmv}$ exhibited higher $\mathrm{I}_{\mathrm{S}}$ than those grown at $1200 \mathrm{ppmv}(n=10$; $P<0.05$; Fig. 2b). Cottonwood trees grown at $400 \mathrm{ppmv}$ $\mathrm{CO}_{2}$ exhibited significantly higher isoprene emission rates than those grown at $800 \mathrm{ppmv}(n=10 ; P<0.05$; Fig. 2c). There was a significant time-dependent effect in the aspen experiment, which caused a decrease in $I_{s}$ with increasing tree age. Thus, the isoprene emission rates of the trees grown in the 600 and $1200 \mathrm{ppmv} \mathrm{CO}_{2}$ treatments (later in the experimental cycle) were, on

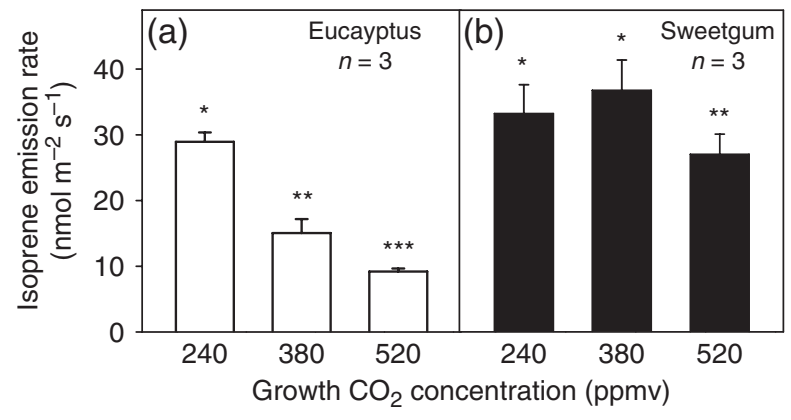

Fig. 1 Isoprene emission rates $\left(\mathrm{I}_{\mathrm{s}}\right)$ for eucalyptus and sweetgum trees grown at different $\mathrm{CO}_{2}$ concentrations in the LYCOG experiment. Error bars $= \pm 1 \mathrm{SE}$. A different number of asterisks next to each data bar indicates differences that are significant at $P<0.05$.

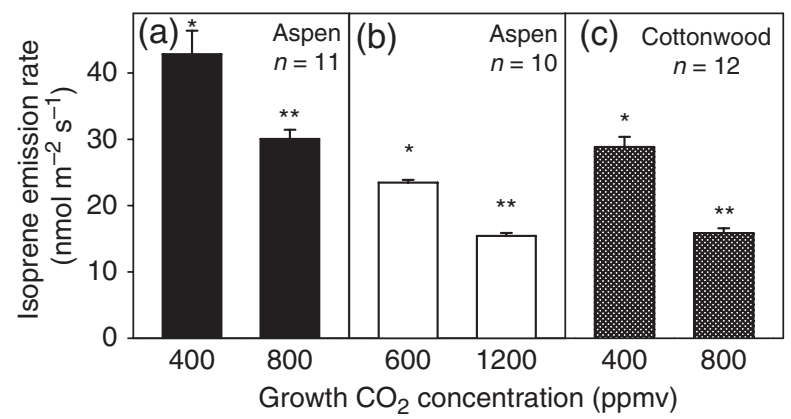

Fig. 2 Isoprene emission rates for aspen and cottonwood trees grown at different $\mathrm{CO}_{2}$ concentrations. Error bars $= \pm 1 \mathrm{SE}$. A different number of asterisks next to each bar indicates differences that are significant at $P<0.05$.

average, lower than those of the trees grown in the 400 and 800 ppmv $\mathrm{CO}_{2}$ treatments.

We used observations of the diurnal pattern of $\mathrm{I}_{\mathrm{s}}$ from a sweetgum leaf grown at $520 \mathrm{ppmv} \mathrm{CO}_{2}$ in the LYCOG experiment, along with the G95 algorithm (the combined model for describing the light and temperature dependence of $\mathrm{I}_{\mathrm{s}}$; Guenther et al., 1995), to predict the effect that growth at high $\mathrm{CO}_{2}$ has on model estimates of the diurnal variability in $\mathrm{I}_{\mathrm{s}}$ (Fig. 3). The diurnal pattern of $\mathrm{I}_{\mathrm{S}}$ was predicted for a leaf grown at ambient $\mathrm{CO}_{2}$ using its basal emission rate (measured at $30^{\circ} \mathrm{C}$ and $1000 \mu \mathrm{mol} \mathrm{m}^{-2} \mathrm{~s}^{-1}$ PPFD) along with measurements of leaf temperature and PPFD recorded throughout a typical day during the Texas measurements (Fig. 3a). These predicted measurements were then compared with actual measurements of $\mathrm{I}_{\mathrm{s}}$ made during the same day on a leaf that had been grown in the elevated- $\mathrm{CO}_{2}$ chamber (i.e., from the 520 ppmv chamber; Fig. 3b). We interpreted the difference between the two to be the error that would occur if one ignored the 'growth $\mathrm{CO}_{2}$ effect' and assumed that the G95 algorithm correctly predicts $\mathrm{I}_{\mathrm{s}}$ for the high- $\mathrm{CO}_{2}$ growth condition. We 


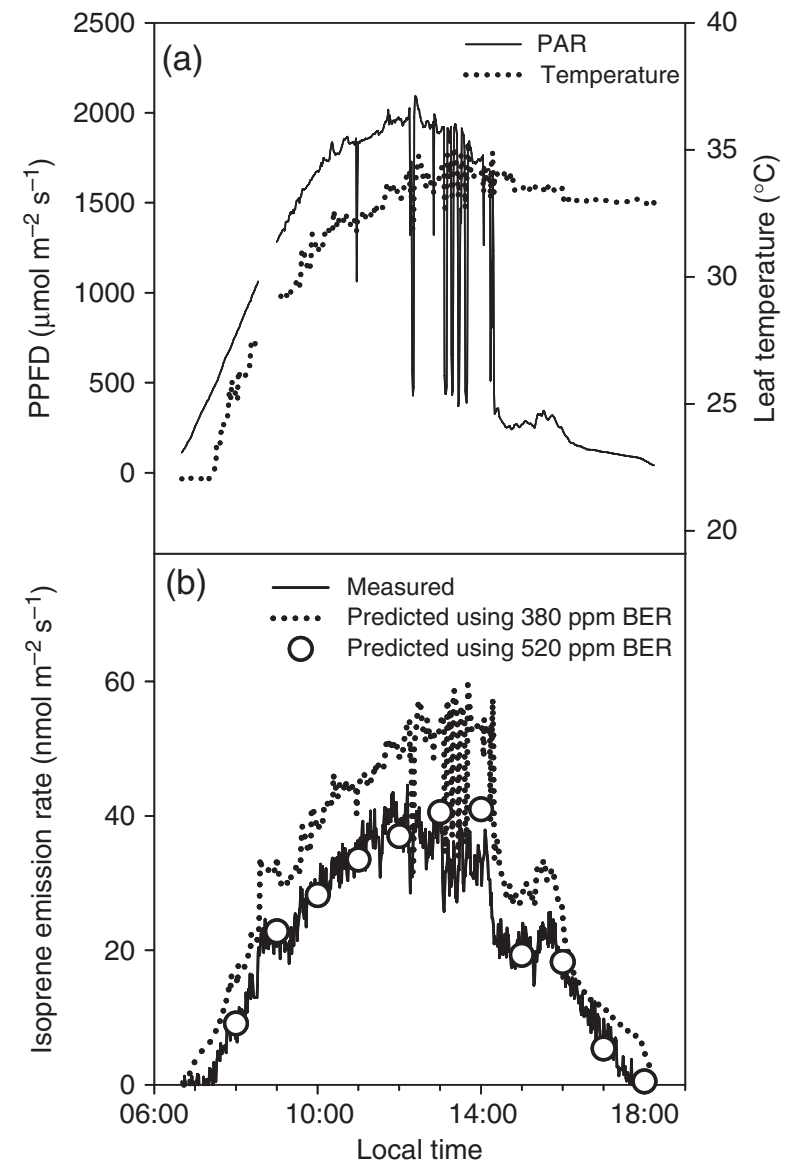

Fig. 3 Effect of using basal emission rates of trees grown at present-day $\mathrm{CO}_{2}$ concentrations to predict the diurnal flux of isoprene from vegetation grown under elevated $\mathrm{CO}_{2}$. Panel (a) shows the diurnal trend in environmental variables (solid line, PPFD; dotted line, leaf temperature). Panel (b) shows the diurnal trend in $\mathrm{I}_{\mathrm{s}}$ for sweetgum trees growing at $520 \mathrm{ppmv} \mathrm{CO}_{2}$ (solid line), modeled $\mathrm{I}_{\mathrm{s}}$ predicted using the average basal emission rate calculated from trees growing at $380 \mathrm{ppmv}$ (dotted line) and 520 ppmv $\mathrm{CO}_{2}$ (open circles).

observed a diurnal pattern in $\mathrm{I}_{\mathrm{s}}$ over the day with low values in the morning, which increased with PPFD and temperature. The estimated $\mathrm{I}_{\mathrm{S}}$ was approximately $15-18 \%$ greater when the growth $\mathrm{CO}_{2}$ effect was ignored, compared with observed values. When measured $\mathrm{I}_{\mathrm{s}}$ was compared with model values calculated using a basal emission rate for the trees grown in the 520 ppmv $\mathrm{CO}_{2}$ chamber, model estimates agreed closely with measured values.

Response of $\mathrm{I}_{\mathrm{s}}$ to changes in $\mathrm{CO}_{2}$ concentration during a single day (short-term response)

When the atmospheric $\left[\mathrm{CO}_{2}\right]$ is changed across the time scale of seconds or minutes, rather than days or weeks,

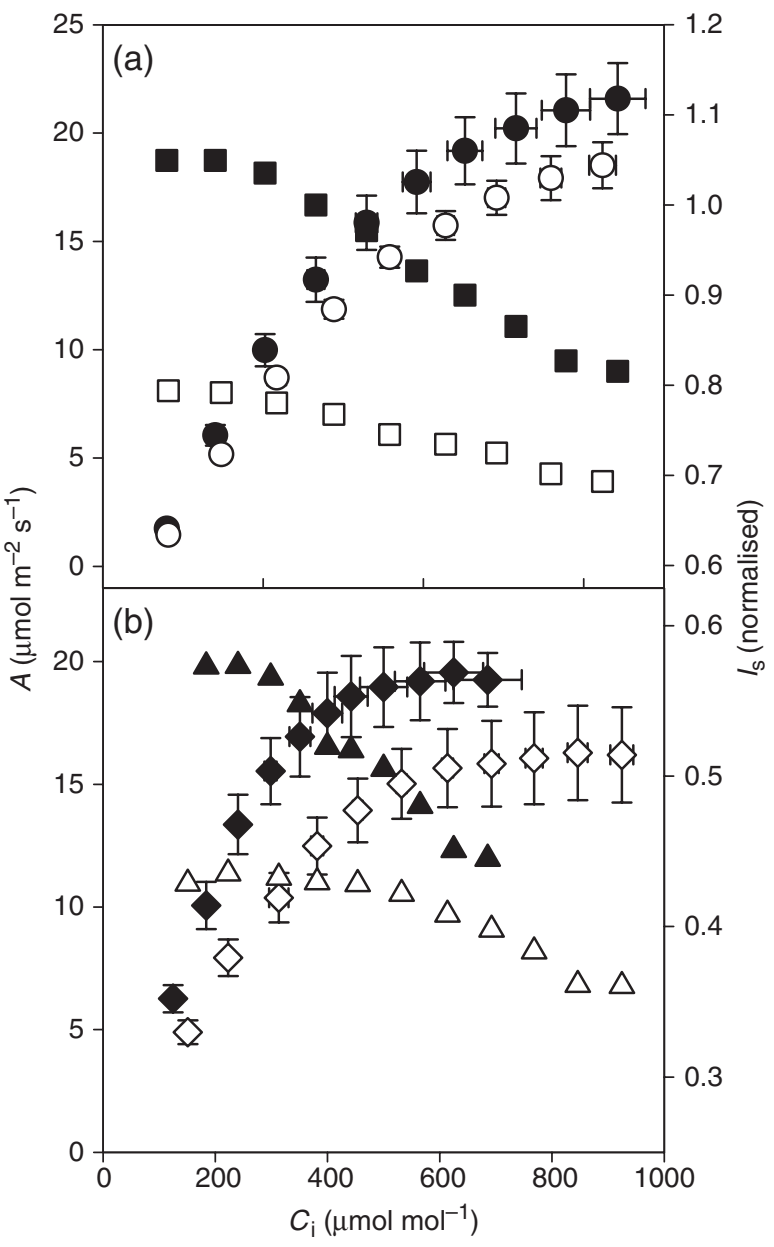

Fig. 4 Carbon assimilation rates (A) and normalized isoprene emission rates measured when $A: C_{i}$ curves were conducted on aspen trees grown at different $\mathrm{CO}_{2}$ concentrations. Isoprene emission rates were normalized by calculating the ratio of isoprene emission rates measured at growth conditions for tress growing at $400 \mathrm{ppmv} \mathrm{CO}_{2}$. Panel (a) shows gas exchange measurements for 12 trees grown at $400 \mathrm{ppmv}$ (A, closed circles; $\mathrm{I}_{\mathrm{s}}$, closed squares; $n=12$ ) and 800 ppmv $\mathrm{CO}_{2}\left(\mathrm{~A}\right.$, open circles; $\mathrm{I}_{\mathrm{s}}$, open squares; $n=12$ ). Panel (b) shows gas exchange measurements for trees grown at $600 \mathrm{ppmv}\left(\mathrm{A}\right.$, closed diamonds; $\mathrm{I}_{\mathrm{s}}$, closed triangle; $n=10)$ and 1200 ppmv $\mathrm{CO}_{2}$ (A, open diamonds; $\mathrm{I}_{\mathrm{S}}$, open triangles; $n=10$ ). Error bars $= \pm 1 \mathrm{SE}$.

the response of $I_{s}$ is driven by adjustments in existing metabolic components, rather than the production of new metabolic components. We refer to this type of response as the 'short-term response'. We measured the response of photosynthetic $\mathrm{CO}_{2}$ assimilation rate (A) and $I_{s}$ to changes in $C_{i}$; the $C_{i}$ value is more relevant to short-term leaf metabolism, than the atmospheric $\left[\mathrm{CO}_{2}\right]$, as it eliminates from the analysis effects caused by stomatal responses to $\mathrm{CO}_{2}$. In order to provide 


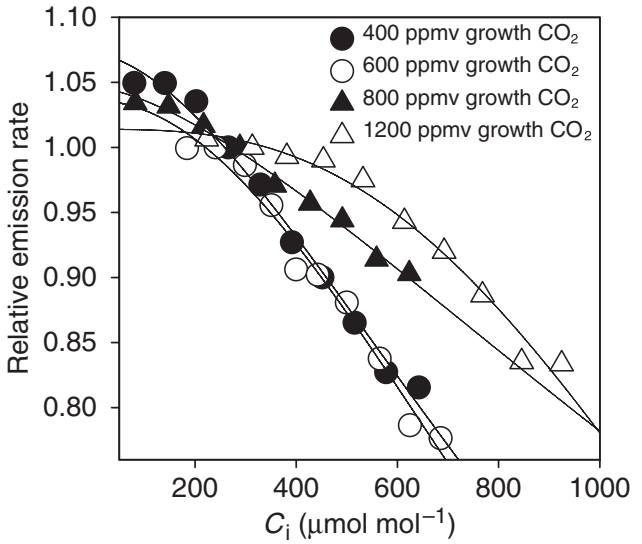

Fig. 5 Response of normalized isoprene emission rate to $\mathrm{C}_{\mathrm{i}}$ for aspen trees grown in four different $\mathrm{CO}_{2}$ concentrations $\left(\left[\mathrm{CO}_{2}\right]\right)$. Isoprene emission rates were normalized by assigning emissions measured at short-term $\left[\mathrm{CO}_{2}\right]$ of $400 \mathrm{ppmv}$, a value of 1.0 for trees from each of the long-term $\mathrm{CO}_{2}$ treatments. Curves were fit to the data using the best fit of Eqn (1).

context for the observed $C_{i}$ values, we note that the average growth $\mathrm{C}_{\mathrm{i}}$ was $265(400 \mathrm{ppmv}$ growth $\left.\mathrm{CO}_{2}\right), 351$ (600 ppmv growth $\left.\mathrm{CO}_{2}\right), 559$ (800 ppmv growth $\mathrm{CO}_{2}$ ), and 925 (1200 ppmv growth $\mathrm{CO}_{2}$ ) ppmv $\mathrm{CO}_{2}$.

$\mathrm{I}_{\mathrm{S}}$ was reduced when leaves were subjected to shortterm increases in $\left[\mathrm{CO}_{2}\right](200-1200 \mathrm{ppmv})$, but the decrease was not linear. At $C_{i}$ values between 200 and 400 ppmv, $I_{s}$ was less sensitive to changes in $C_{i}$, compared with the response between 400 and $800 \mathrm{ppmv}$. At $C_{i}$ values above 800 ppmv, $I_{s}$ again became less sensitive to changes in $\left[\mathrm{CO}_{2}\right]$ resulting in an overall sigmoidalshaped response pattern. Long-term effects of growth at elevated $\mathrm{CO}_{2}$ appeared to influence the trend in $\mathrm{I}_{\mathrm{s}}$ recorded during short-term changes in $\mathrm{CO}_{2}$. Generally, the higher the growth $\mathrm{CO}_{2}$, the less sensitive the $\mathrm{I}_{\mathrm{s}}$ from aspen leaves were to short-term variations in $C_{i}$ (Fig. 5).

\section{Modeling the response of isoprene emission to elevated $\mathrm{CO}_{2}$}

The relationship between isoprene emission rate and $\mathrm{C}_{\mathrm{i}}$, for the short-term effect, resembled an inverse sigmoidal response surface (Fig. 4). Sigmoidal relations between the velocity of an enzyme-catalyzed reaction and the concentration of a substrate or allosteric effector often reflect second-order influences involving competing or cooperative substrates (Cook \& Cleland, 2007). In such systems, reaction velocity is typically affected by exponential amplification. Building on this past knowledge, and starting from existing models (e.g., the Hill equation), we designed an empirically based relation- ship that fits the isoprene- $C_{i}$ response pattern:

$$
\mathrm{C}_{\mathrm{Ci}}=\mathrm{I}_{\mathrm{s} \max }-\left[\frac{\mathrm{I}_{\mathrm{S} \max }\left(\mathrm{C}_{\mathrm{i}}\right)^{h}}{\left(\mathrm{C}^{*}\right)^{h}+\left(\mathrm{C}_{\mathrm{i}}\right)^{h}}\right],
$$

where $C_{C i}$ is the overall $C_{i}$ scaling factor, intended to scale $I_{s}$ to the progressive inhibitory effects of increasing $\mathrm{C}_{\mathrm{i}}, \mathrm{I}_{\mathrm{s} \max }$ is the estimated asymptote at which further decreases in $C_{i}$ have a negligible effect on the isoprene emission rate $\left(\mathrm{I}_{\mathrm{s}}\right), \mathrm{C}^{*}$ and $h$ are Hill-type scaling coefficients used to calibrate the sigmoidal slope of the relationship between $\mathrm{I}_{\mathrm{s}}$ and $\mathrm{C}_{\mathrm{i}}$. The terms $\mathrm{C}^{*}$ and $h$ are derived empirically, with $C^{*}$ carrying units of ppmv (analogous to the $K_{\mathrm{m}}$ of the Michaelis-Menten model of enzyme kinetics) and $h$ is unitless. The model ignores the fact that as $C_{i}$ decreases toward zero, $I_{s}$ eventually decreases from its low $C_{i}$ maximum (Loreto \& Sharkey, 1990); however, this effect generally occurs at extremely low $C_{i}$ ( $<100$ ppmv in the study by Loreto \& Sharkey, 1990), beyond the range relevant to plants, except those under the most severe stress.

The model presented in Eqn (1) is intended to complement the scaling coefficients $\mathrm{C}_{\mathrm{L}}$ and $\mathrm{C}_{\mathrm{T}}$ (Guenther et al., 1991, 1993, 1995) which are typically used to adjust a normalized (basal) emission rate $\left(\mathrm{I}_{\mathrm{sb}}\right)$ (sometimes called the 'emission factor') to incident light intensity $\left(\mathrm{C}_{\mathrm{L}}\right)$ and prevailing leaf temperature $\left(\mathrm{C}_{\mathrm{T}}\right)$. In combination with these previously defined coefficients, the new scaling coefficient, $\mathrm{C}_{\mathrm{Ci}}$, can be used to scale $\mathrm{I}_{\mathrm{sb}}$ (typically determined at a leaf temperature of $30^{\circ} \mathrm{C}$, an incident PPFD of $1000 \mu \mathrm{mol} \mathrm{m}^{-2} \mathrm{~s}^{-1}$ and, in this case, the $\mathrm{C}_{\mathrm{i}}$ that occurs at an ambient atmospheric $\left[\mathrm{CO}_{2}\right]$ of $400 \mathrm{ppmv}$ ) to instantaneous combinations of these factors that differ from the 'basal' state:

$$
\mathrm{I}_{\mathrm{s}}=\mathrm{I}_{\mathrm{sb}}\left(\mathrm{C}_{\mathrm{T}} \times \mathrm{C}_{\mathrm{L}} \times \mathrm{C}_{\mathrm{Ci}}\right) .
$$

A discussion of the general derivation of Eqn (1) is given in Appendix A.

The values of $\mathrm{C}_{\mathrm{Ci}}$ and its component factors are affected by differences in $\left[\mathrm{CO}_{2}\right]$ during growth (Fig. 5 ); in other words, the shape of the shorter term response is influenced by the longer term response. This means that one set of empirically determined parameters in Eqn (1) will not suffice, but rather the model will need to be 'tuned' to the prevailing growth $\left[\mathrm{CO}_{2}\right]$. Overall, the model described the response of the standardized $I_{S}$ to $C_{i}$ for trees grown over a range of four atmospheric $\left[\mathrm{CO}_{2}\right]$ relatively well (Fig. 5). As discussed above, the measured responses are ideally sigmoidal. The model, which has a form that predicts an overall sigmoidal response, predicted a response surface that was not obviously sigmoidal within the range of $C_{i}$ observations used for the curve fits of Fig. 5 . The asymptotic shape of the response predicted by Eqn 
Table 1 Empirically determined parameter values for Eqn (1) from aspen trees grown at four different $\mathrm{CO}_{2}$ concentrations

\begin{tabular}{lcccc}
\hline \multirow{5}{*}{ Growth $\mathrm{CO}_{2}$ concentration } \\
\cline { 2 - 5 } Parameter & $400 \mathrm{ppmv}$ & $600 \mathrm{ppmv}$ & $800 \mathrm{ppmv}$ & $1200 \mathrm{ppmv}$ \\
\hline $\mathrm{I}_{\mathrm{s} \max }$ & 1.072 & 1.036 & 1.046 & 1.014 \\
$h$ & 1.7000 & 2.0125 & 1.5380 & 2.8610 \\
$\mathrm{C}^{*}$ & 1218 & 1150 & 2025 & 1525 \\
\hline
\end{tabular}

(1) at high $C_{i}$ is not predicted to occur until higher $C_{i}$ values and lower standardized $I_{s}$ than those observed in our experiments. Thus, the form of the model is not a perfect fit to the patterns in the observed data, but provides a good description. Further observations at $\mathrm{C}_{\mathrm{i}}$ greater than those measured during these experiments are required to evaluate whether the sigmoidal nature of Eqn (1) is truly justified.

We have determined the sets of parameter values that best accommodate Eqn (1) to the normalized $C_{i}$ response of aspen leaves grown at the four different $\left[\mathrm{CO}_{2}\right]$ in the growth-chamber experiment (Table 1). There is a clear effect due to tree aging in the experiment in that the values for $h$ were higher, $C^{*}$ lower, and $\mathrm{I}_{\mathrm{s} \max }$ lower, for the trees grown at 600 and $1200 \mathrm{ppmv}$, compared with those grown at 400 and 800 ppmv, respectively. Taking this effect into account, from the results presented in Table 1 and Fig. 5, we can state that $\mathrm{I}_{\mathrm{s} \max }$ tends to decrease and $\mathrm{C}^{*}$ tends to increase as growth $\left[\mathrm{CO}_{2}\right]$ increases; the effect on $h$ was variable.

We also assessed the utility in deploying Eqn (1) to predict the longer term, growth $\mathrm{CO}_{2}$ responses (Fig. 6). In a previous study, Possell et al. (2005) provided a regression model describing the normalized $\mathrm{I}_{\mathrm{s}}$ for a variety of species in response to a range of $\left[\mathrm{CO}_{2}\right]$, when grown and measured at the same $\left[\mathrm{CO}_{2}\right]$. We have used this regression as a reference curve after a reduction of the $\left[\mathrm{CO}_{2}\right]$ by the multiplier 0.7 , to reflect estimated $\mathrm{C}_{\mathrm{i}}$, rather than $C_{a}$. We then plotted the mean normalized $I_{s}$ for aspen trees grown at each of the four growth chamber $\left[\mathrm{CO}_{2}\right]$ vs. the estimated $\mathrm{C}_{\mathrm{i}}$. When applied to the latter dataset, Eqn (1) provided a good fit. The data from our observations, along with the fit provided by Eqn (1), was also relatively close to the corrected regression obtained from the Possell et al. (2005) analysis at $C_{i}$ above 400 ppmv. At lower $C_{i}$, the analysis of Possell et al. (2005) predicted continuous increases in $\mathrm{I}_{\mathrm{s}}$ whereas our results for aspen (Fig. 4) and sweetgum (Fig. 1) predict an asymptote as $I_{s \max }$ is approached. The parameter values obtained from the fit of Eqn (1) to the growth $\mathrm{CO}_{2}$ response of aspen is presented in Table 2.

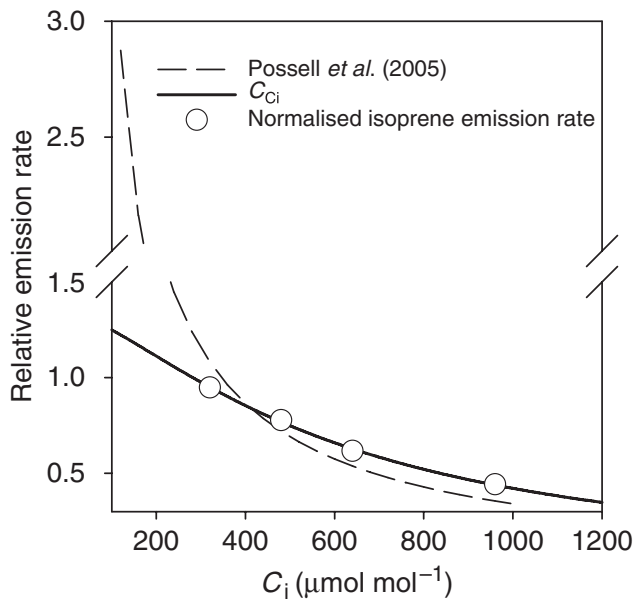

Fig. 6 Response of normalized isoprene emission rates to changes in growth $\mathrm{CO}_{2}$ concentration $\left(\left[\mathrm{CO}_{2}\right]\right.$ ) estimated by Possell et al. (2005) (broken line) with their ambient $\left[\mathrm{CO}_{2}\right]$ corrected by the multiplier 0.7 to estimate $C_{i}$. Mean response of normalized isoprene emission rates of aspen leaves, measured at their growth $\left[\mathrm{CO}_{2}\right]$ and plotted as a function of $\mathrm{C}_{\mathrm{i}}$ (open circles) $(n=10-12)$, and best-fit line provided by Eqn (1) (solid line).

Table 2 Empirically determined parameter values for Eqn (1) from pooled data of aspen trees grown at four different $\mathrm{CO}_{2}$ concentrations

\begin{tabular}{lc}
\hline Parameter & 'Best-fit' value \\
\hline $\mathrm{I}_{\mathrm{s} \max }$ & 1.344 \\
$h$ & 1.4614 \\
$\mathrm{C}^{*}$ & 585 \\
\hline
\end{tabular}

\section{Discussion}

Although a small number of studies have reported that $\mathrm{I}_{\mathrm{s}}$ from different tree species is not affected by elevated atmospheric $\left[\mathrm{CO}_{2}\right]$ (Buckley, 2001; Rapparini et al., 2004), a larger body of studies report a significant $\mathrm{CO}_{2}$-induced reduction in $\mathrm{I}_{\mathrm{S}}$ (Monson \& Fall, 1989; Loreto \& Sharkey, 1990; Sharkey et al., 1991; Loreto et al., 2001b; Rosenstiel et al., 2003; Centritto et al., 2004; Scholefield et al., 2004; Possell et al., 2005; Monson et al., 2007). (However, these past reports tend to mix together the long-term and short-term effects of $\left[\mathrm{CO}_{2}\right]$.) We found that $\mathrm{I}_{\mathrm{s}}$ from eucalyptus, sweetgum, cottonwood, and aspen trees is reduced when grown with higher $\left[\mathrm{CO}_{2}\right]$. These observations provide evidence for two, potentially connected, mechanisms of response to elevated $\mathrm{CO}_{2}$ : one that occurs nearly instantaneously and presumably involves adjustments to metabolite pools and enzyme activities in the existing isoprene 
metabolism of a leaf, and one that occurs more slowly, over the growth period of a leaf, and presumably involves adjustments to the expression of the genes that regulate isoprene emission. It is possible that there are connections between these responses. Recent studies have shown that the activity of the cytosolic enzyme PEP carboxylase increases following instantaneous increases in leaf high $\mathrm{C}_{\mathrm{i}}$ (the short-term response) (Rosenstiel et al., 2003), and during periods of high sugar loads (such as might occur during a long-term response to growth at elevated $\mathrm{C}_{\mathrm{a}}$ ) (Rontein et al., 2002). Common changes in the activity of this single enzyme may, therefore, link the short- and long-term responses of $I_{s}$ to $\left[\mathrm{CO}_{2}\right]$. We did not track the relative response kinetics for adjustments at these two time frames, nor did we track changes in the metabolite levels of enzyme activities of key enzymes; both of these types of observations would help clarify the nature of these controls and the potential for commonality between them. We note that in past studies it has been found that isoprene and monoterpene emissions respond similarly to elevated $\left[\mathrm{CO}_{2}\right]$, especially in those oak species known to emit monoterpenes from a biochemical basis similar to that of isoprene (Loreto et al., 2001a; Rapparini et al., 2004). It is possible that the responses to $\left[\mathrm{CO}_{2}\right]$ that we observed for $\mathrm{I}_{\mathrm{s}}$ are explained by mechanisms that also operate to control the $\mathrm{CO}_{2}$ response of monoterpene emissions. However, further research on the controls over monoterpene emissions are required to test this hypothesis.

In the past, models of $\mathrm{I}_{\mathrm{s}}$ have focused on PPFD and temperature as driving variables, and have relied on empirical equations known informally as the 'Guenther algorithms' (Guenther et al., 1991, 1993, 1995). When deployed into regional or global models that aim to predict atmospheric chemistry, the Guenther algorithms provide no basis for describing the direct short-term or long-term effects of changes in atmospheric $\left[\mathrm{CO}_{2}\right]$ (Monson et al., 2007). We found that the error in predicting the $\mathrm{I}_{\mathrm{s}}$ using the Guenther algorithms, without inclusion of the growth $\left[\mathrm{CO}_{2}\right]$ effect alone, is significant (Fig. 3). In order to better serve future modeling efforts, we developed a quantitative model to describe the short- and long-term responses to $\mathrm{C}_{\mathrm{i}}$, which could be used in combination with the traditional Guenther algorithms to predict the direct effects of $\left[\mathrm{CO}_{2}\right]$ on $\mathrm{I}_{\mathrm{s}}$. The model was only tested with aspen leaves so, at present, it would have to be deployed with the caveat that its fit to other species has not been established. Nevertheless, given the similarities in the responses of four different species to elevated $\mathrm{CO}_{2}$ in the short- and long-term and the results of Possell et al. (2005), we predict that the model will provide a relatively accurate description of the effects of future dynamics in atmospheric $\left[\mathrm{CO}_{2}\right]$ on $\mathrm{I}_{\mathrm{s}}$.
The model that we developed is similar in its empirical formulation to that used for the Guenther algorithms. While all of these equations are derived from 'best-of-fit' functions, the observed responses are, at least for the Guenther algorithms, driven by underlying biochemical mechanisms and, therefore, there is good reason to suspect that, to some degree at least, these empirical functions also reflect biochemical mechanisms (Guenther et al., 1991, 1993). Now, the question arises as to whether the empirically derived $\mathrm{CO}_{2}$ model also has mechanistic underpinnings. We have conducted an analysis to address this question and concluded that there is reason to believe that the form of Eqn (1) reflects the competition for PEP substrate between biochemical processes in the cytosol and chloroplasts of $C_{3}$ leaf cells, which in the case of varying $C_{i}$ is driven by the activity of the enzyme PEP carboxylase (Appendix A). Briefly, as $\mathrm{C}_{\mathrm{i}}$ increases, and the activity of PEP carboxylase is enhanced, reductions in the transport of PEP into the chloroplasts will reduce the level of pyruvate needed for isoprene biosynthesis in inverse, rectangular hyperbolic fashion, or sigmoidal fashion, mirroring the Michaelis-Menten-type response of PEP carboxylase to one or both of its substrates, $\mathrm{HCO}_{3}^{-}$and PEP. We should note that while we have based the model on $\mathrm{C}_{\mathrm{i}}$, our metabolic justification would lead us to conclude that the inorganic $\mathrm{C}$ concentration in the cytosol of mesophyll cells is more relevant. If indeed, the activity of PEP carboxylase drives the $\mathrm{CO}_{2}$ response, then its response to $\mathrm{HCO}_{3}^{-}$might be more relevant than $\mathrm{C}_{\mathrm{i}}$. Basing the model on cytosolic $\mathrm{HCO}_{3}^{-}$, rather than $\mathrm{C}_{\mathrm{i}}$ will not change the overall shape of the modeled $\mathrm{CO}_{2}$ response, but it may alter the relevant atmospheric $\left[\mathrm{CO}_{2}\right]$ where sigmoidal transitions in the response occur.

We need to address the possibility that the response of $\mathrm{I}_{\mathrm{s}}$ to $\left[\mathrm{CO}_{2}\right]$ is due to artifactual effects of growing the trees in pots, with restricted rooting volume, rather than direct responses to the prevailing $\left[\mathrm{CO}_{2}\right]$. In the two separate growth chamber experiments with aspen trees, the initial slope of the $A: C_{i}$ relationship, an indicator of photosynthetic carboxylation capacity, was lower when plants were grown at elevated $\left[\mathrm{CO}_{2}\right]$ (Fig. $4 a$ and b), suggesting that part or all of the response to the higher growth $\mathrm{CO}_{2}$ involved downregulation of the carboxylating enzyme, Rubisco. This is a common response in experiments involving elevated $\left[\mathrm{CO}_{2}\right]$, especially when potted plants are used (Thomas \& Strain, 1991). The cause of the response is thought to involve a build-up photosynthate in photosynthetic cells, followed by downregulation of photosynthetic genes to bring the photosynthetic supply of sugars back into balance with photosynthetic demand (Long et al., 2004). It is not likely that these shifts in sugar supply and demand 
directly affect isoprene emission rate, at least not from a substrate perspective, as the rate at which photosynthetic substrate used to synthesize isoprene is typically $1 \%$ or less the rate of photosynthate production (Monson \& Fall, 1989). Additionally, we note that we observed the same downregulation of $\mathrm{I}_{\mathrm{S}}$ when trees were grown at elevated $\left[\mathrm{CO}_{2}\right]$ in two different Free Air $\mathrm{CO}_{2}$ Enrichment (FACE) experiments, one that also involved aspen trees, and neither of which involved pot-grown trees (Monson et al., 2007). A recent metaanalysis of FACE experiments showed that, like previous potted-plant experiments, a downregulation of Rubisco content and activity occurs, presumably due to signals received at the molecular level due to a build-up of leaf sugars when plants are grown at elevated $\left[\mathrm{CO}_{2}\right]$ (Long et al., 2004). Thus, these general responses of central metabolism appear to reflect a direct response to growth at elevated $\left[\mathrm{CO}_{2}\right]$, not an experimental artifact. Using cultured tomato cells grown with different supply rates of glucose, Rontein et al. (2002) showed that a build-up of leaf sugars also results in the upregulation of PEP carboxylase activity. Flexibility in the expression of PEP carboxylase genes in response to cellular carbohydrate supply may be a general design feature of plant metabolic controls, especially those controlling the expression of anabolic pathways (Rontein et al., 2002), and thus may explain the inhibition of $\mathrm{I}_{\mathrm{s}}$ in trees grown at elevated $\left[\mathrm{CO}_{2}\right]$. The fact that these similar responses were observed in plants from both potted-tree experiments, and FACE experiments, suggest that they are due to direct responses to the atmospheric $\mathrm{CO}_{2}$ environment, not the soil-rooting environment.

With regard to overall $\mathrm{CO}_{2}$ response of isoprene emissions, our results are similar to those of Possell et al. (2005), who compiled data from several studies of the effects long-term changes in $\left[\mathrm{CO}_{2}\right]$ on $\mathrm{I}_{\mathrm{S}}$. The response reported by Possell et al. (2005) exhibits a decrease from a maximum $\mathrm{I}_{\mathrm{s}}$ that is approximately three times greater than that measured in present-day $\left[\mathrm{CO}_{2}\right]$ before asymptotically leveling off at $I_{S}$ an order of magnitude lower than those measured at the lowest $\left[\mathrm{CO}_{2}\right]$. We calculated a similar result for $\mathrm{I}_{\mathrm{S}}$ at $\left[\mathrm{CO}_{2}\right]$ at the higher end of this range (Fig. 6). However, because of a reduction in the sensitivity of $\mathrm{I}_{\mathrm{S}}$ to changes in $\mathrm{CO}_{2}$ at low $\mathrm{C}_{\mathrm{i}}$ values, our observations lead to the conclusion that the isoprene $/ \mathrm{CO}_{2}$ response curve of Possell et al. (2005) overestimates $\mathrm{I}_{\mathrm{s}}$ at low $\left[\mathrm{CO}_{2}\right]$. The differences in these analyses will cause uncertainties in efforts to model atmospheric chemistry during past epochs characterized by low $\left[\mathrm{CO}_{2}\right]$, and must be reconciled in order to understand biochemical controls over $\mathrm{I}_{\mathrm{s}}$ at low $\mathrm{C}_{\mathrm{i}}$. If indeed the principal biochemical limitation at low $C_{i}$ is the availability of G3P, then it is difficult to explain a continued increase in $I_{s}$ as $C_{i}$ decreases (as seen in the Possell et al. results) unless a mechanism is identified that would produce G3P at progressively higher rates. Alternatively, if the primary limitation to isoprene biosynthesis rate at low $C_{i}$ is pyruvate, supplied from the import of PEP into the chloroplast, and the increase in PEP import at low $C_{i}$ is due to the progressive limitation of PEP carboxylase in the cytosol, then a mechanism would have to be identified for the continued glycolytic production of PEP in the face of reduced triose-phosphate export from the chloroplast (to explain the results of the current study). There is a clear basis for further work on the controls over isoprene biosynthesis at low $\left[\mathrm{CO}_{2}\right]$.

It is estimated that without action to limit greenhouse gas emissions, global mean temperature will increase $2-4{ }^{\circ} \mathrm{C}$ over the next 100 years (IPCC, 2007) with a concomitant rise in background tropospheric $\left[\mathrm{O}_{3}\right]$ and an increase in the atmospheric loading of organic aerosols. Methane is also of interest to atmospheric chemists because its atmospheric lifetime is highly sensitive to perturbations in hydroxyl radical concentrations (Valdes et al., 2005). Within the context of these effects, any change in the atmospheric loading of isoprene could significantly influence climate change predictions. The downregulation of isoprene emission at elevated $\left[\mathrm{CO}_{2}\right]$ that we have reported must be considered within the context of predicted increases in NPP due to increased plant growth in elevated $\left[\mathrm{CO}_{2}\right]$ (Monson et al., 2007). However, the effects of elevated $\left[\mathrm{CO}_{2}\right]$ on NPP are complex. For example, Gielen et al. (2001) noted that the stimulation of biomass production relative to control plots at different FACE sites may be transient and limited only to the first few years of growth. Also, 8 years of experimental data collected at the Oak Ridge FACE site revealed that increases in NPP occurred primarily through belowground increases in biomass and not through increases in aboveground, isoprene-emitting biomass (Norby et al., 2004). More recently Finzi et al. (2007) reported a 25\% increase in productivity for forest FACE experiments at Oak Ridge National Laboratory, Rhinelander (Harshaw Experimental Forest), Duke Forest, and POP-EuroFace, much of which is associated with increases in canopy biomass. Clearly, the future effects of global change on the flux of isoprene from forest systems cannot be reconciled without consideration of the direct effects of increasing atmospheric $\left[\mathrm{CO}_{2}\right]$ on both NPP and isoprene synthesis. At the time that Monson et al. (2007) made their case, there was no good quantitative model for use in carrying out this type of analysis. We now present a model that appears to work well in explaining the response of isoprene emissions to atmospheric $\left[\mathrm{CO}_{2}\right]$ and is consistent with the past Guenther 
algorithms that are used in larger scale models of atmospheric chemistry. It is expected that this model can now be used to address some of these important questions concerning atmospheric chemistry in the face of future global change projections.

\section{Acknowledgements}

This work was supported by NSF Grant 0543895 and EPA Grant RD-83145301. We thank Dr Todd Rosenstiel for assistance in the initial establishment of the growth chambers and for stimulating discussions on the relationship between PEP carboxylase activity and $\mathrm{I}_{\mathrm{S}}$ and Dr Almut Arneth for stimulating discussions on the relationships between isoprene emissions and atmospheric $\left[\mathrm{CO}_{2}\right]$. The authors also thank Dr Keith Julian for discussions on the application of mathematical functions in biological systems. We also take this opportunity to thank the staff at the LYCOG project for their assistance in establishing and caring for plant material in the $\mathrm{CO}_{2}$ tunnels.

\section{References}

Arneth A, Miller PA, Scholze M, Hickler T, Schurgers G, Smith B, Prentice IC (2007) Process-based estimates of terrestrial ecosystem isoprene emissions: incorporating the effects of a direct $\mathrm{CO}_{2}$-isoprene interaction. Atmospheric Chemistry and Physics, $\mathbf{7}$, 31-53.

Arneth A, Schurgers G, Hickler T, Miller PA (2008) Effects of species composition, land surface cover, $\mathrm{CO}_{2}$ concentration and climate on isoprene emissions from European forests. Plant Biology, 10, 150-162.

Brasseur GP, Kiehl JT, Mueller J-F, Schneider T, Granier C, Tie XX, Hauglustaine D (1998) Past and future changes in global tropospheric ozone: impact on radiative forcing. Geophysical Research Letters, 25, 3807-3810.

Buckley P (2001) Isoprene emissions from a Florida scrub oak species grown in ambient and elevated carbon dioxide. Atmospheric Environment, 35, 631-634.

Centritto M, Nascetti P, Petrilli L, Raschi A, Loreto F (2004) Profiles of isoprene emission and photosynthetic parameters in hybrid poplars exposed to free-air $\mathrm{CO}_{2}$ enrichment. Plant, Cell and Environment, 27, 403-412.

Claeys M, Graham B, Vas G et al. (2004) Formation of secondary organic aerosols through photooxidation of isoprene. Science, 303, 1173-1176.

Cook PF, Cleland WW (2007) Enzyme Kinetics and Mechanism. Garland Science, London.

Delwiche CF, Sharkey TD (1993) Rapid appearance of ${ }^{13} \mathrm{C}$ in biogenic isoprene when ${ }^{13} \mathrm{CO}_{2}$ is fed to intact leaves. Plant, Cell and Environment, 16, 587-591.

Fehsenfeld FC, Calvert J, Fall R et al. (1992) Emissions of volatile organic compounds from vegetation and the implications for atmospheric chemistry. Global Biogeochemical Cycles, 6, 389-430.

Finzi AC, Norby RJ, Calfapietra C et al. (2007) Increases in nitrogen uptake rather than nitrogen-use efficiency support higher rates of temperate forest productivity under elevated $\mathrm{CO}_{2}$. Proceedings of the National Academy of Sciences of the United States of America, 104, 14014-14019.
Gielen B, Calfapietra C, Sabatti M, Ceulemans R (2001) Leaf area dynamics in a closed poplar plantation under free-air carbon dioxide enrichment. Tree Physiology, 21, 1245-1255.

Guenther A, Hewitt CN, Erickson D et al. (1995) A global-model of natural volatile organic-compound emissions. Journal of Geophysical Research - Atmospheres, 100, 8873-8892.

Guenther AB, Monson RK, Fall R (1991) Isoprene and monoterpene emission rate variability: observations with eucalyptus and emission rate algorithm development. Journal of Geophysical Research, 96, 10799-10808.

Guenther AB, Zimmerman PR, Harley PC, Monson RK, Fall R (1993) Isoprene and monoterpene emission rate variability model evaluations and sensitivity analyses. Journal Geophysical Research - Atmospheres, 98, 12609-12617.

Harley PC, Monson RK, Lerdau MT (1999) Ecological and evolutionary aspects of isoprene emission from plants. Oecologia, 118, 109-123.

Houweling S, Dentener F, Lelieveld J (1998) The impact of nonmethane hydrocarbon compounds on tropospheric photochemistry. Journal of Geophysical Research - Atmospheres, 103, 10673-10696.

IPCC (2007) Fourth assessment report of the intergovernmental panel on climate change. Synthesis Report. Cambridge University Press, Cambridge, UK. 52 P.

Johnson CE, Collins WJ, Stevenson DS, Derwent RG (1999) Relative roles of climate and emissions changes on future tropospheric oxidant concentrations. Journal of Geophysical Research, 104, 18631-18645.

Johnson CE, Stevenson DS, Collins WJ, Derwent RG (2001) Role of climate feedback on methane and ozone studied with a coupled ocean-atmosphere-chemistry model. Geophysical Research Letters, 28, 1723-1726.

Lathiere J, Hauglustaine DA, De Noblet-Ducoudre N, Krinner G, Folberth GA (2005) Past and future changes in biogenic volatile organic compound emissions simulated with a global dynamic vegetation model. Geophysical Research Letters, 32, L20818, doi: 10.1029/2005GL024164.

Lerdau M, Gray D (2003) Ecology and evolution of light dependent and light independent phytogenic volatile organic carbon. New Phytologist, 157, 199-211.

Liao H, Chen WT, Seinfeld JH (2006) Role of climate change in global predictions of future tropospheric ozone and aerosols. Journal Geophysical Research, 111, D12304, doi: 10.1029/ 2005JD006852.

Lichtenthaler HK, Schwender J, Disch A, Rohmer M (1997) Biosynthesis of isoprenoids in higher plant chloroplasts proceeds via a mevalonate independent pathway. FEBS Letters, 400, 271-274.

Long SP, Ainsworth EA, Rogers A, Ort DR (2004) Rising atmospheric carbon dioxide: plants face the future. Annual Review of Plant Biology, 55, 591-628.

Loreto F, Centritto M, Barta C, Calfapietra C, Fares S, Monson RK (2007) The relationship between isoprene emission rate and dark respiration rate in white poplar (Populus alba L.) leaves. Plant, Cell and Environment, 30, 662-669.

Loreto F, Fischbach RJ, Schnitzler JP, Ciccioli P, Brancaleoni E, Calfapietra C, Seufert G (2001a) Monoterpene emission and 
monoterpene synthase activities in the Mediterranean evergreen oak Quercus ilex L. grown at elevated $\mathrm{CO}_{2}$ concentrations. Global Change Biology, 7, 709-717.

Loreto F, Mannozzi M, Maris C, Nascetti P, Ferranti F, Pasqualini S (2001b) Ozone quenching properties of isoprene and its antioxidant role in leaves. Plant Physiology, 126, 9931000.

Loreto F, Sharkey TD (1990) A gas exchange study of photosynthesis and isoprene emission in red oak (Quercus rubra L.). Planta, 182, 523-531.

Loreto F, Sharkey TD (1993) On the relationship between isoprene emission and photosynthetic metabolites under different environmental conditions. Planta, 189, 420-424.

Monson RK (2002) Volatile organic compound emissions from terrestrial ecosystems: a primary biological control over atmospheric chemistry. Israel Journal of Chemistry, 42, $29-42$.

Monson RK, Fall R (1989) Isoprene emission from aspen leaves influence of environment and relation to photosynthesis and photorespiration. Plant Physiology, 90, 267-274.

Monson RK, Holland EA (2001) Biospheric trace gas fluxes and their control over tropospheric chemistry. Annual Review of Ecology and Systematics, 32, 547-576.

Monson RK, Trahan N, Rosenstiel TN et al. (2007) Isoprene emission from terrestrial ecosystems in response to global change: minding the gap between models and observations. Philosophical Transactions of the Royal Society, A, 365, 1677-1695.

Norby RJ, Ledford J, Reilly CD, Miller NE, O'Neill EG (2004) Fine-root production dominates response of a deciduous forest to atmospheric $\mathrm{CO}_{2}$ enrichment. Proceedings of the National Academy of Sciences of the United States of America, 101, 9689 9693.

Pierce T, Geron C, Bender L, Dennis R, Tonnesen G, Guenther A (1998) Influence of increased isoprene emissions on regional ozone modeling. Journal of Geophysical Research - Atmospheres, 103, 25611-25629.

Poisson N, Kanakidou M, Crutzen PJ (2000) Impact of nonmethane hydrocarbons on tropospheric chemistry and the oxidizing power of the global troposphere: 3-dimensional modeling results. Journal of Atmospheric Chemistry, 36, 157-230.

Polley HW, Johnson HB, Fay PA, Sanabria J (2008) Initial response of evapotranspiration from tallgrass prairie vegetation to $\mathrm{CO}_{2}$ at subambient to elevated concentrations. Functional Ecology, 22, 163-171.

Possell M, Hewitt CN, Beerling DJ (2005) The effects of glacial atmospheric $\mathrm{CO}_{2}$ concentrations and climate on isoprene emissions by vascular plants. Global Change Biology, 11, 60-69.

Potter CS, Alexander SE, Coughlan JC, Klooster SA (2001) Modeling biogenic emissions of isoprene: exploration of model drivers, climate control algorithms, and use of global satellite observations. Atmospheric Environment, 35, 6151-6165.

Rapparini F, Baraldi R, Miglietta F, Loreto F (2004) Isoprenoid emission in trees of Quercus pubescens and Quercus ilex with lifetime exposure to naturally high $\mathrm{CO}_{2}$ environment. Plant, Cell and Environment, 27, 381-391.

Rontein D, Dieuaide-Noubhani M, Dufourc EJ, Raymond P, Rolin D (2002) The metabolic architecture of plant cells stability of central metabolism and flexibility of anabolic path- ways during the growth cycle of tomato cells. Journal of Biological Chemistry, 277, 43948-43960.

Rosenstiel TN, Potosnak MJ, Griffin KL, Fall R, Monson RK (2003) Increased $\mathrm{CO}_{2}$ uncouples growth from isoprene emission in an agriforest ecosystem. Nature, 421, 256-259.

Sanadze GA (1957) Emission of organic matter by leaves of Robina pseudaecia L. Soobsch Acad Nauk, GSSR, 19, 183.

Sanadze GA (1964) Light-dependent excretion of isoprene by plants. Photosynthesis Research, 2, 701-707.

Scholefield PA, Doick KJ, Herbert BMJ, Hewitt CN, Schnitzler JP, Pinelli P, Loreto F (2004) Impact of rising $\mathrm{CO}_{2}$ on emissions of volatile organic compounds: isoprene emission from Phragmites australis growing at elevated $\mathrm{CO} 2$ in a natural carbon dioxide spring. Plant, Cell and Environment, 27, 393-401.

Sharkey TD, Loreto F, Delwiche CF (1991) The biochemistry of isoprene emission from leaves during photosynthesis. In: Trace Gas Emissions by Plants (eds Sharkey TD, Holland B, Mooney HA), pp. 153-184. Academic Press, New York.

Shim C, Wang YH, Choi Y, Palmer P, Abbot DS, Chance K (2005) Constraining global isoprene emissions with GOME formaldehyde column measurements. Journal of Geophysical Research, 110, D24301, doi: 10.1029/2004JD005629.

Tao Z, Jain AK (2005) Modeling of global biogenic emissions for key indirect greenhouse gases and their response to atmospheric $\mathrm{CO}_{2}$ increases and changes in land cover and climate. Journal of Geophysical Research, 110, D21309, doi: 10.1029/ 2005JD005874.

Thomas RB, Strain BR (1991) Root restriction as a factor in photosynthetic acclimation of cotton seedlings grown in elevated atmospheric carbon dioxide. Plant Physiology, 96, 627634.

Tingey DT, Evans R, Gumpertz M (1981) Effects of environmental conditions on isoprene emission from live oak. Planta, 152, 565-570.

Valdes PJ, Beerling DJ, Johnson DE (2005) The ice age methane budget. Geophysical Research Letters, 32, L02704, doi: 10.1029/ 2004GL021004.

Wolfertz M, Sharkey TD, Boland W, Kühnemann F, Yeh S, Weise SE (2003) Biochemical regulation of isoprene emission. Plant, Cell and Environment, 26, 1357-1364.

Zeng G, Pyle JA (2003) Changes in tropospheric ozone between 2000 and 2100 modeled in a chemistry-climate model. Geophysical Research Letters, 30, 1392, doi: 10.1029/2002GL016708.

\section{Appendix A. The biochemical and mathematical justification for $\mathrm{C}_{\mathrm{Ci}}$}

The $\mathrm{CO}_{2}$-dependent algorithm (for calculation of $\mathrm{C}_{\mathrm{Ci}}$ ) that we present in Eqn (1) was derived through a Bayesian process whereby prior knowledge about the biochemistry of isoprene biosynthesis was used to infer the key relationships. Evidence obtained to date suggests that the $\mathrm{CO}_{2}$ dependence of $\mathrm{I}_{\mathrm{s}}$ is determined by two interacting factors: (1) at low $\left[\mathrm{CO}_{2}\right], \mathrm{I}_{\mathrm{S}}$ becomes progressively uncoupled from photosynthetic G3P production, and is sustained by the mobilization of G3P from stored carbohydrate reserves (Monson \& Fall, 1989; Wolfertz et al., 2003); (2) at high $\left[\mathrm{CO}_{2}\right], \mathrm{I}_{\mathrm{s}}$ becomes progressively, but 


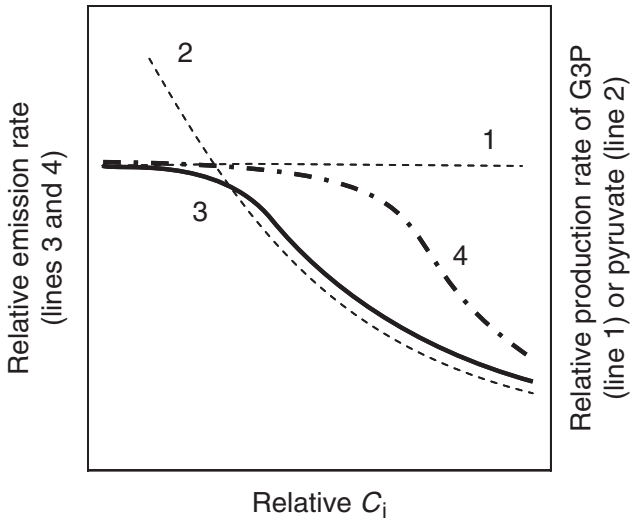

Fig. A1 Proposed relations among the supply of G3P from stored reserves (Line 1), which is assumed to be constant in the face of changing $\mathrm{C}_{\mathrm{i}}$; the supply of pyruvate provided by transport of PEP into the chloroplast from the cytosol (Line 2) and controlled by the Michaelis-Menten-type response of PEP carboxylase to increased $C_{i}$; a normalized response of $I_{S}$ to changes in $C_{i}$ similar to what was observed for trees grown at 400 ppmv $\mathrm{CO}_{2}$ (Line 3); and a normalized response of $\mathrm{I}_{\mathrm{S}}$ to changes in $\mathrm{C}_{\mathrm{i}}$ similar to what was observed for trees grown at 800 ppmv $\mathrm{CO}_{2}$ (Line 4).

indirectly, limited by increased activity of the cytosolic enzyme phosphoenolpyruvate carboxylase (PEPc) (Rosenstiel et al., 2003; Loreto et al., 2007). In order to explain the overall response of $\mathrm{I}_{\mathrm{s}}$ to changes in $C_{i}$, we assumed the velocity of the reaction catalyzed by PEPc increases as $C_{i}$ increases, and within some relatively narrow range of increasing $C_{i}, I_{s}$ undergoes a transition from G3P limitation to pyruvate limitation (Fig. A1). Above this transition range, $I_{S}$ would be controlled by the Michaelis-Menten-type response of PEPc to increases in $\left[\mathrm{CO}_{2}\right]$; below this transition range, $I_{S}$ would be controlled by the rate of G3P mobilization from carbohydrate reserves. According to this explanation, the sigmoidal shape of the $\mathrm{CO}_{2}$ response represents a switch between the metabolic limitations imposed by one of two processes. Within the context of this hypothesis, the growth of plants at higher $\left[\mathrm{CO}_{2}\right]$ may shift the transition range between the two limiting processes to higher $C_{i}$ values, consistent with the results of Fig. 5.

Mathematically, a switch in controlling functions can be related to the same independent variable by a Heaviside function, which takes the general form:

$$
H(x)= \begin{cases}f_{1}(x) & \text { if } c<x_{1}, \\ f_{2}(x) & \text { if } c \geq x_{1},\end{cases}
$$

where $c$ is a critical threshold value of $x$, which allows the form of the function to be toggled between two alternatives. When combined to a single function we can write:

$$
f(x)=f_{1}(x) u_{x 1}+f_{2}(x) u_{x 2},
$$

which allows $f_{1}$ to control the value of the dependent variable below the critical switch (designated as $u_{x 1}$ ), and the sum of $f_{1}$ and $f_{2}$ to control its value at or above the critical switch (designated as $u_{x 2}$ ). In designing a relationship to describe the $\mathrm{CO}_{2}$-dependence of $\mathrm{I}_{\mathrm{s}}$, we can write:

$$
\mathrm{C}_{\mathrm{Ci}}=\mathrm{I}_{\mathrm{s} \max } u_{\mathrm{C} 11}-\left[\frac{\mathrm{I}_{\mathrm{s} \max } \mathrm{C}_{\mathrm{i}}}{\mathrm{C}_{\mathrm{i} 50}+\mathrm{C}_{\mathrm{i}}}\right] u_{\mathrm{Ci} 2} .
$$

Equation (A3) describes a switch in the $\mathrm{CO}_{2}$ response such that below a critical $\left[\mathrm{CO}_{2}\right]$ value $\left(\mathrm{C}_{\mathrm{i} 1}\right)$, the maximum value of $\mathrm{I}_{\mathrm{S}}$ is limited by the rate of mobilization of G3P from carbohydrate reserves; at or above the critical $C_{i}$ value $\left(C_{i 2}\right)$, the response is driven by the Michaelis-Menten-type activity of an enzyme, which we assume to be PEP carboxylase. The coefficient $\mathrm{C}_{\mathrm{i} 50}$ is analogous to $K_{\mathrm{m}}$ a Michaelis constant that constrains the firstorder region of a modeled, rectangular hyperbolic response of $I_{s}$ to $\mathrm{C}_{\mathrm{i}}$.

In practical terms, it would be an improvement if we could design an analytical form of Eqn (A3) that does not depend on stepwise triggers, but rather describes a continuous dependence of $I_{s}$ on $C_{i}$. We have found that the following equation, which retains the essential features of Eqn (A3), works well to describe the $\mathrm{CO}_{2}$ dependence in continuous fashion:

$$
\mathrm{C}_{\mathrm{Ci}}=\mathrm{I}_{\mathrm{s} \max }-\left[\frac{\mathrm{I}_{\mathrm{s} \max }\left(\mathrm{C}_{\mathrm{i}}\right)^{h}}{\left(\mathrm{C}^{*}\right)^{h}+\left(\mathrm{C}_{\mathrm{i}}\right)^{h}}\right],
$$

where $h$ is a tunable coefficient that permits the right-hand side of the equation to be 'penalized' exponentially at low $\mathrm{C}_{\mathrm{i}}$ and thus allow $\mathrm{C}_{\mathrm{Ci}}$ to move toward the limit defined by Term I, but to be 'amplified' exponentially at high $\mathrm{C}_{\mathrm{i}}$ and thus allow $\mathrm{C}_{\mathrm{Ci}}$ to move toward greater dependence on Term II. We have re-defined $C_{i 50}$ as $C^{*}$; with this definition, $C^{*}$ becomes a more generalized $C_{i}$ scalar, rather than a strict analogue to the Michaelis constant, $K_{\mathrm{m}}$. By introducing $\mathrm{C}^{*}$, we can scale Eqn (A4) differentially to account for growth- $\mathrm{CO}_{2}$ effects on the switch between the two competing metabolic controls; as growth $\mathrm{CO}_{2}$ increases, $\mathrm{C}^{*}$ should increase, shifting the penalty phase of the right-hand side of Eqn (A4) to higher $C_{i}$ values. 